\title{
Trade policies, firm strategies, and adaptive reconfigurations of global value chains
}

\author{
Gary Gereffi ${ }^{1}$, Hyun-Chin Lim ${ }^{2}$ \\ and Joonkoo Lee ${ }^{3}$
}

${ }^{1}$ Department of Sociology, Duke University, Durham, NC 27708, USA; ${ }^{2}$ Department of Sociology, Seoul National University, Seoul 08826, Republic of Korea; ${ }^{3}$ School of Business, Hanyang University, Seoul 04763, Republic of Korea

\section{Correspondence:}

J Lee, School of Business, Hanyang University, Seoul 04763, Republic of Korea e-mail: joonklee@hanyang.ac.kr

\begin{abstract}
The recent U.S.-China trade conflicts cast new light on the role of trade policies in global value chains (GVCs). Contrary to the expectation that trade restrictions lead to the shrinking or disruption of GVCs, our article posits that the unintended consequences of trade policies (both restrictions and trade agreements) are amplified by the prevalence and organizational complexity of GVCs. We anchor our argument in the historical evolution of three classic GVCs - apparel, automobiles, and electronics - from the 1970s to the present. Our framework highlights the dynamic interaction between GVC-oriented trade policies and firm strategies, which often has counterintuitive implications in terms of upgrading outcomes for the countries and companies involved in these GVCs. While trade policies often provide momentum for an adaptive reconfiguration of GVCs, firms' strategic actions are crucial in modifying the geographic and organizational features of GVCs in ways that support their longevity. Firm strategies can mediate the effect of trade policies on GVC configurations in two ways: (1) firms can accommodate trade restrictions and trade agreements by altering supply and demand locations and by switching supply-chain partners; and (2) firms pursue diverse strategies to upgrade their value chain activities, leveraging the shifting geographies associated with new trade rules.
\end{abstract}

Journal of International Business Policy (2021) 4, 506-522.

https://doi.org/ | 0.1057/s42214-021-00 I02-z

Keywords: trade restrictions; trade war; firm strategies; global value chains; GVC configurations; unintended consequences

\section{INTRODUCTION}

The recent trade tension between the United States and China is raising questions about the future of global value chains (GVCs), a cross-border system of decentralized and coordinated production. Over the last several decades, GVCs have been the cornerstone of the global economy, driving the expansion of international trade and reshaping the way countries and firms produce, trade, and invest (OECD, 2013; UNCTAD, 2013; World Bank, 2020). The rise of GVCs has transformed our thinking about how global industries and international business operate and how value is created and distributed therein, with profound implications for the upgrading prospects of countries, firms, and workers (Gereffi, 2018a, 2019a).
Received: 1 September 2019

Revised: 7 January 2021

Accepted: 14 January 2021

Online publication date: 16 March 2021 
Trade policy and regulations always influence the structure and dynamics of GVCs (Azmeh, 2019; Curran, Nadvi \& Campling, 2019; Van Assche \& Gangnes, 2019), and the nation-state plays a key role in formulating and enforcing policy and regulations on international trade and investment (Horner \& Alford, 2019). However, recent escalating tensions, including the U.S.-China trade war, cast new light and raise uncertainty about the role of trade policy and regulations in the cross-border flows of intermediate goods and value-added tasks in GVCs (Gereffi, 2018b; Blanchard, 2019).

This article examines the impact of trade policy, including both trade restrictions and trade agreements, on the geographic and organizational configurations of GVCs, and the way this relationship is mediated by the strategies of lead firms and suppliers in three major GVCs: apparel, automobiles, and electronics. Trade restrictions generally refer to any government policy that limits the free flow of goods and services across borders, including tariffs, quotas, voluntary export restraints (VERs), and technical barriers like product safety and quality standards. We argue that trade restrictions can have unintended consequences in a world of GVCs, amplifying uncertainty across complex production and sourcing networks in the global economy. In response, the firms affected seek to bypass trade restrictions with two main types of strategies: (a) switching production locations, end markets and/or suppliers; and (b) upgrading value chain activities. These firm strategies can prompt the geographic and organizational reconfiguration of GVCs, although the way this process unfolds varies by sectors and time period.

Below we first discuss key conceptual elements of our argument. We illustrate our claims by examining the role of trade policies, both restrictions and trade agreements, in the historical evolution of three archetypical manufacturing GVCs (apparel, automobiles and electronics) from the 1970s to the present. Finally, we discuss the relevance of our findings for GVC-oriented policies.

\section{TRADE POLICIES, FIRM STRATEGIES, AND GVC RESTRUCTURING}

\section{The Unintended Consequences of Trade Restrictions in a GVC World}

Since his inauguration in January 2017, U.S. President Donald Trump and his administration have imposed various trade restrictions against a host of countries, including its allies. ${ }^{1}$ The protectionist moves culminated in a U.S. trade conflict with China, which started in early 2018 and featured U.S. tariff hikes on imports from China and an American trade ban against Huawei, the Chinese electronics and telecom giant, over national security concerns and China's retaliatory counter-tariffs. Despite a first-phase deal in January 2020, many contentious issues are largely unresolved (Swanson \& Rapperport, 2020), and the stand-off between the two countries has intensified amid the COVID-19 pandemic (Rudd, 2020). The trade war is notable not only because it involves the world's two largest economies tightly connected through GVCs, but also because GVCs continued to expand in recent decades amidst lowered trade barriers and a rules-based regime under the World Trade Organization (WTO), which provided predictability in trade and investment (Azmeh, 2019; Fajgelbaum, Goldberg, Kennedy \& Khandelwal, 2020). Now, the tide is apparently turning in the opposite direction, raising the specter of the shrinkage, if not demise, of GVCs (Chor, 2019).

However, given the prevalence of GVCs nowadays, the impacts of trade restrictions can be different from those in the pre-GVC world, and some measures can have unintended consequences (Bellora \& Fontagné, 2019; Blanchard, 2019). In the GVC world, diverse trade patterns other than a simple bilateral exchange of final goods exist, and trade is intertwined with foreign direct investment (FDI) and outsourcing (UNCTAD, 2013; Head \& Mayer, 2019). As a result, the effect of trade restrictions can be amplified beyond the two disputing partners or the targeted final products. For instance, when U.S. or third-country firms outsource to or invest in China in order to export to the U.S., they are immediately exposed to the U.S. restrictions against China. Thus, higher U.S. import tariffs penalize many non-Chinese firms (including American ones) that use China as a sourcing location where imported inputs are assembled for export to the U.S, as in the case of Apple's iPhone. $^{2}$ At the same time, higher tariffs on imported intermediate goods from China can hurt U.S. domestic firms using these inputs. Tesla, an American electric vehicle company, uses imported parts from China, and higher U.S. tariffs will drive up its U.S. production costs (Matousek, 2018).

Furthermore, because "not all imports are equal" (Gereffi, 2018b: 436), the impact and magnitude of trade restrictions are highly specific and vary not only by sector (Erken, Giesbergen \& Nauta, 2019) as 
well as over time, but also by the type of GVC linkages a country or firm is involved in (Gereffi, Humphrey \& Sturgeon, 2005; Van Assche \& Gangnes, 2019). Thus, it is increasingly difficult to pinpoint the winners and losers of trade policies because they are not always straightforward in a GVC world. The gains and losses depend not only on a country's or firm's engagement with its target market, but also the way it is involved in GVCs through third countries and the time period involved.

\section{Firm Strategies: Switching and Upgrading}

A GVC perspective highlights the linkages of "the macro-level of international trade and investment with the micro-level of factories, jobs, and local communities through the meso-level lens of global industries" (Gereffi, 2019a: 199). Thus, it emphasizes the role of firms in shaping the flows of international trade and FDI based on their geographic and organizational choices with regard to GVCs (Gereffi \& Lee, 2016). ${ }^{3}$ Confronted with trade restrictions, the strategies of both lead firms and suppliers can alter the geographic and organizational dimensions of GVCs (Pananond, Gereffi \& Pedersen, 2020). We argue, therefore, that (a) in response to trade restrictions, firms seek to mitigate negative impacts on their operations with switching and economic upgrading strategies; and (b) these strategic actions generate adaptive configurations that can enhance the resilience of GVCs.

\section{Switching strategies}

In the face of trade restrictions, firms can use varied strategies of locational switching for production, end markets, or suppliers. First, production switching involves moving production to other countries little or not affected by the restrictions. This is a widely used practice by exporters to circumvent country-specific tariffs or other trade policy shocks (Van Assche \& Gangnes, 2019). Apparel producers, for example, frequently circumvented the constraint of import quotas in one country by shifting their production to another where quota was still available (Gereffi, 1999). A second form of trade diversion is market switching, the strategy of selling products in alternative countries. Chinese firms, for instance, can shift from exports to domestic sales to avoid heightened barriers in foreign markets. This option works far better in economies with large domestic markets than for those with small ones; the latter may opt for growing market opportunities in the Global South instead (Horner \& Nadvi,
2018). A third firm strategy is supplier switching. Firms can change their sourcing partners to circumvent a restriction like the U.S. ban against Huawei and its suppliers. ${ }^{4}$ In response, Huawei can turn to domestic suppliers instead of foreign-owned ones, or switch to suppliers from countries not constrained by the measure. While production switching has been studied more often in the international business (IB) field (Van Assche \& Gangnes, 2019), the latter two switching strategies by firms are relevant in the current context of the China-U.S. trade conflicts.

\section{Economic upgrading}

Firms, both buyers and suppliers, can also attempt to circumvent trade restrictions by altering their production profile through upgrading, defined as capturing more value by improving processes or products or moving into higher value-added segments in GVCs (Humphrey \& Schmitz, 2002; Gereffi, 2019b). In response to VERs in the 1980s, Japanese carmakers not only expanded outward FDI for production in the U.S. market, a form of production switching, but also upgraded to a higher value-added luxury-car product line, an example of product upgrading (Benjamin, 1999). East Asian apparel producers, limited by restrictive U.S. import quotas in the 1980s and 1990s, also implemented a dual strategy: (a) they shifted production to quota-free countries; and (b) pursued functional upgrading via design and production services like trading and logistics (Gereffi, 1999).

This process of functional upgrading is a dynamic trajectory (Gereffi, 2019b). Firms acquire new capabilities as they move from the assembly of imported inputs to original equipment manufacturing (OEM) and original design manufacturing (ODM) up to original brand manufacturing (OBM). Thus, upgrading triggered by trade restrictions can make a long-term impact on the competitive capabilities of the countries or firms involved.

Switching and upgrading can be pursued separately or simultaneously. Firms can produce, sell or source (import) the same product in the same way but via different locations. However, switching may also be closely intertwined with upgrading. For example, agrifood exporters may upgrade their products in order to shift their sales to final markets with higher safety and quality standards (Lee, Gereffi \& Beauvais, 2012). When exporters switch to the domestic market, they tend to have an opportunity to functionally upgrade by 
incorporating value chain activities not encouraged or allowed in the export chains, such as marketing and branding (Navas-Alemán, 2011).

\section{Geographic and Organizational Reconfigurations of GVCs}

Strategic actions by firms to divert trade restrictions through switching or upgrading often result in the reconfiguration of the geographic and organizational structure of GVCs. These GVC reconfigurations in turn can have significant implications for the economic and social upgrading of countries, firms, and workers (Frederick \& Gereffi, 2011).

GVCs can be geographically dispersed or concentrated (Lee et al., 2012). GVCs expand their geographic footprint as lead firms spread value chain activities into a greater number of countries and regions. Alternatively, value chains may be clustered at a world-regional scale, which can be facilitated by regional free trade agreements (e.g., NAFTA, the Dominican Republic-Central America Free Trade Agreement (CAFTA-DR), and the African Growth and Opportunity Act) or broader regional integration schemes (e.g., the European Union). Over the last few decades, many manufacturing GVCs have concentrated their production in China due to the twin advantages of low-cost and highvolume production (Lee \& Gereffi, 2013; Autor, Dorn \& Hanson, 2016). Chinese dominance as a global exporter across a wide range of manufactured goods has prompted a rise in protectionism among China's main trade partners, including the United States, Europe and Japan (UNCTAD, 2019; Bown, 2020). In the face of trade restrictions imposed on one country, such as China in the current era, firms can make various geographic choices: bringing production back home ('reshoring'); diverting it to another foreign country; or investing in new upgraded capabilities at home or other offshore locations (Fratocchi, Di Mauro, Barbieri, Nassimbeni \& Zanoni, 2014).

Geographic reconfigurations can occur with or without an organizational reconfiguration among firms. At one extreme, lead firms can vertically integrate their value chains at a firm, country, or regional level, from product conception and research and development (R\&D) all the way through production, distribution and sales. The opposite pole is the fragmentation of GVCs through offshoring and outsourcing into finely sliced tasks, traded across national borders, and relegated by the lead firm to independent suppliers. The growing capacity and capabilities of suppliers, such as transnational contract manufacturers, can prompt lead firms to outsource more complicated functions, advancing the organizational fragmentation of GVCs (Sako \& Zylberberg, 2019; Pananond et al., 2020).

Despite the crucial role played by firm strategies in the unintended consequences of trade restrictions and GVC reconfigurations, a host of other factors can affect firms' strategic choices and GVC configurations. These include sectoral specificities, policy and regulatory overlap, international institutions, GVC governance structures, and disruptive events like global financial crises and the COVID-19 pandemic, as illustrated in our analysis below. ${ }^{5}$

\section{THE INTERPLAY OF TRADE RESTRICTIONS AND FIRM STRATEGIES IN THE APPAREL, AUTOMOTIVE, AND ELECTRONICS GVCS}

This section illustrates how trade policies (both restrictions and trade agreements) have prompted firm strategies that alter the geographic and organizational configurations of GVCs in three sectors: apparel, automobiles and electronics. GVCs play an important role in all these industries, which also account for a significant share of trade between the U.S. and China and are currently subject to U.S. tariff hikes. Distinct trade policy measures, facilitative and restrictive, were used in each sector at different periods, leading to varied GVC configurations over time.

Below we discuss and illustrate the evolution of these three GVCs from the 1970s to the present, focusing on the extent to which trade policies had similar or different impacts on each GVC and the ways the affected firms, both lead firms and suppliers, responded to the barriers.

\section{Apparel GVCs}

The apparel industry is one of the hallmarks of economic globalization at the end of the twentieth century. As a basic consumer good rooted in laborintensive production, apparel epitomized the fragmented and globally dispersed production networks associated with buyer-driven GVCs (Gereffi, 1994). In the late 1960s and 1970s, garment manufacturers sought low-cost suppliers for apparel products, beginning with assembly operations such as those located in the maquiladora sector along Mexico's border with the United States (Grunwald \& Flamm, 1985) and German apparel firms outsourcing assembly tasks to low-cost suppliers in Central and Eastern Europe (Fröbel, Heinrichs \& 
Kreye, 1980). As U.S. retailers and brand marketers began to explore the advantages of offshore production for their private label (store brand) and designer clothing lines, apparel sourcing became global. There was a growing emphasis on "fullpackage" suppliers in Hong Kong, Taiwan and South Korea that were able to provide the textiles, design, sample making, logistics, financial and other services required by a diversified range of "big buyers" (retailers, brands, and factoryless producers) located in the large, high-income markets of North America and Western Europe (Gereffi, 1999).

At the outset, apparel production and sourcing networks were highly fragmented internationally because they were driven by the quota system defined by the Multi-Fiber Arrangement (MFA) established in the 1970s. The quota system followed by the U.S. and much of Western Europe allowed apparel-importing economies to set quantitative limits (quotas) on clothing exporters throughout the world, which led to several welldocumented migrations of production in the apparel GVC. According to data for the United States, the world's largest apparel market, in 1983 U.S. apparel imports were $\$ 9.7$ billion; two-thirds $(68 \%)$ of this total came from Northeast Asia (primarily Hong Kong, Taiwan and South Korea); $12 \%$ came from Southeast and South Asia; $6 \%$ from Mexico, Central America and the Caribbean; and $14 \%$ from all other countries. By 1997, as U.S. apparel imports skyrocketed more than fivefold to $\$ 48.5$ billion, just one-third (33\%) of these imports came from Northeast Asia (including China, the largest apparel exporter in that year); $23 \%$ came from Southeast and South Asia; $16 \%$ from Central America and the Caribbean; 11\% from Mexico; and 16\% from the rest of the world (Gereffi, 1999: 50).

How can we explain these significant trade shifts? Most of the major apparel exporting economies had very low wages, but this factor alone cannot account for the proliferation of new Asian and Caribbean suppliers, whose U.S. market share expanded in the 1990s even though their wage rates were often considerably higher than China's. A more precise explanation focuses on trade policies (quotas and preferential tariffs) and exchange rates ${ }^{6}$ used to protect developed-country markets from a flood of low-cost apparel imports, especially from Asia. Despite their intent, however, the imposition of quotas and apparel tariffs produced contradictory results (Gereffi, 1999). Protectionism often heightened the competitive capabilities of apparel exporters in developing countries, who learned to make more sophisticated items that were far more profitable than simple ones.

Figure 1 illustrates the interconnected industrial upgrading trajectories in the Asian apparel value chain. First, Japan and the most advanced East Asian textile and apparel producers (Hong Kong, South Korea and Taiwan) were pushed much earlier than other countries in the region to functionally upgrade from garments to higher-value textile, fiber and machinery exports to other economies in the region. ${ }^{7}$ Second, there is a regional division of labor in the Asian apparel value chain, whereby countries at different levels of development form a multitier production hierarchy with a variety of export roles (Gereffi, 1996). This synergistic economic ecosystem applies to a number of regional value chains (e.g., East Asian apparel and electronics, North American motor vehicles, and European commercial aircraft), which helps explain why they are a stable and resilient feature of the global economy.

A final dimension in the evolution of the apparel GVC is its reproduction through the mechanism of triangle manufacturing, which is a direct response to the protectionist quotas and tariffs that required production to move from countries with higher wages and capabilities to less advanced apparel suppliers (Gereffi, 1999: 60). In triangle manufacturing, which was initiated by the East Asian newly industrializing economies (NIEs) (Hong Kong, Taiwan and South Korea) in the 1970s and 1980s, U.S. buyers continued to place their orders with the NIE firms they sourced from in the past, which in turn shifted some or all of the requested production to affiliated offshore factories in less developed regions of Asia (e.g., China, Indonesia, Vietnam, Cambodia), Central America and the Caribbean, and Sub-Saharan Africa (see Frederick \& Gereffi, 2011; Morris, Staritz \& Barnes, 2011; Bair \& Gereffi, 2014). This pattern institutionalizes a three-tiered structure that permits the East Asian NIEs to continue to upgrade their exports to higher value items, while also using FDI and exports of textile intermediate goods to the third-country exporters that have minimal quota and tariff restrictions, and retain relatively low wages.

\section{Automotive GVCs}

Through the 1970s, Japanese automakers rapidly expanded their market share in the U.S. with lowerpriced, small-sized cars with better fuel efficiency. This led U.S. carmakers and auto workers' unions to 
Figure 1 Restructuring and upgrading in Asian textile and apparel GVCs.

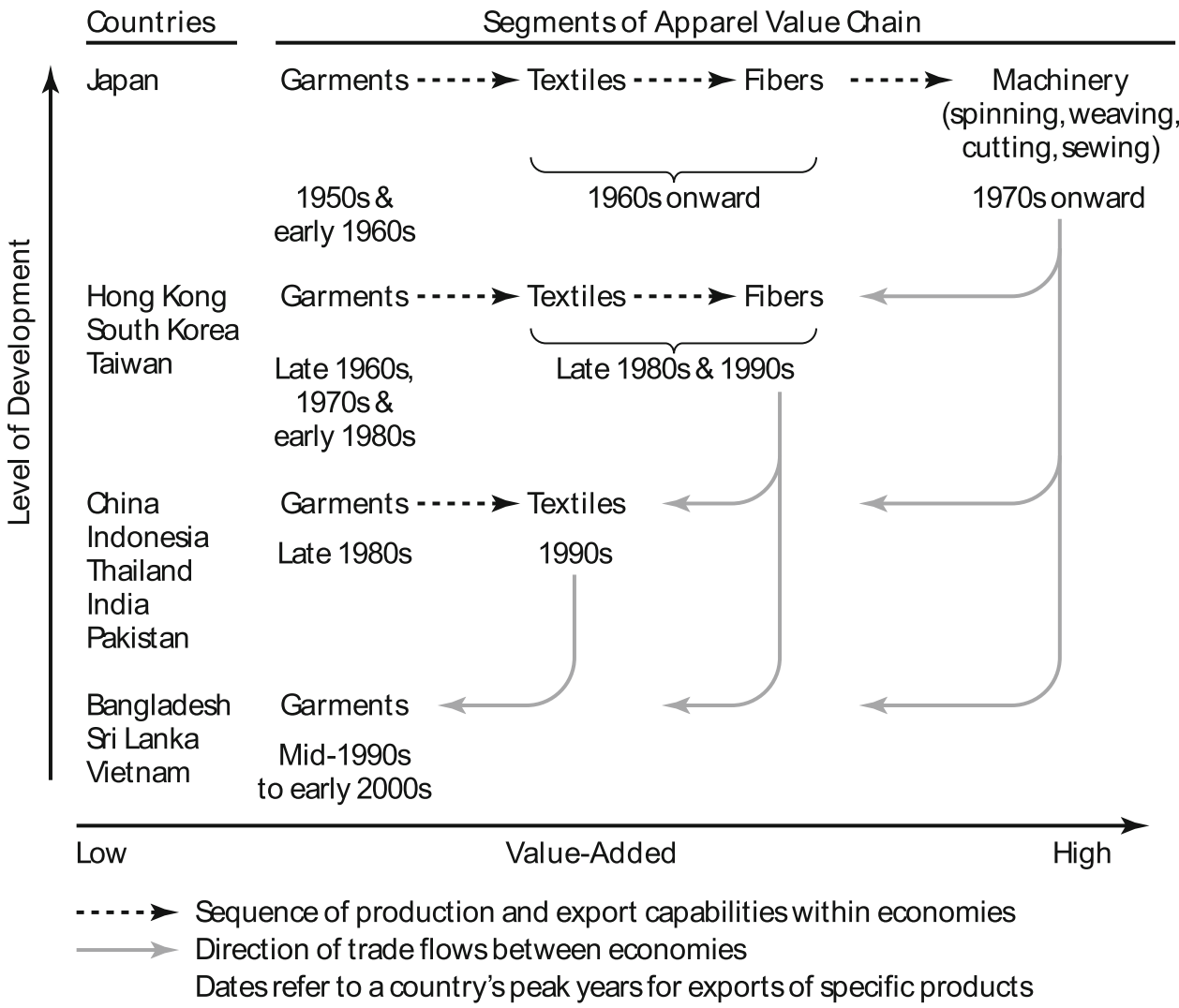

Source: Gereffi (2018: 158). petition import relief, and the Reagan administration put strong pressure on Japan. In response, Japan agreed in 1981 to comply with VERs that limited the number of autos it exported to the U.S. market each year. ${ }^{8}$ The VER agreement was renewed multiple times and maintained until 1994, despite the fact that Japan's car exports to the U.S. had fallen below the quota level since 1986 (Benjamin, 1999).

In the face of U.S.-imposed VERs and a strong Japanese yen vis-à-vis the U.S. dollar after the Plaza Accord, Japanese carmakers took measures to circumvent trade restrictions and unfavorable export conditions, combining the strategies of upgrading and production switching. First, to maximize profitability under the constraint of quotas, they upgraded their mix of auto exports by prioritizing more expensive cars. Notable was the creation of luxury product lines with separate brands, i.e., Honda's Acura, Nissan's Infiniti, and Toyota's Lexus, all launched by the late 1980s in North America.

At the same time, they used production switching strategies, first, by shipping unassembled or partially assembled vehicles to Taiwan and South
Korea where they were assembled and exported to the U.S. market. More importantly, Japanese automakers heavily invested in U.S. production facilities to circumvent the VERs that regulated car imports from Japan but not domestically produced cars by Japanese carmakers (Sturgeon \& Florida, 2004). This FDI-based "transplant" production, also prompted by FDI-oriented incentives by U.S. local governments, ${ }^{9}$ dramatically transformed the geography of the automotive GVC. By 1995, two thirds of the passenger vehicles sold by Japanese firms in the U.S. were domestically produced (Florida \& Kenney, 1991). The strategy was emulated by European and Korean carmakers as well (Sturgeon, Van Biesebroeck \& Gereffi, 2008).

However, unlike the apparel case, the automotive GVCs did not adopt full-scale global sourcing. Instead, regional production systems have become the dominant pattern of organization since the mid-1990s (Pavlínek, 2015). This was not only attributed to technical and market forces but also to regulatory and political factors. Regional trade agreements, notably NAFTA and EU regionalization in the 1990s, incentivized carmakers to invest in 
regional sourcing networks, at the same time moving production to lower-cost locations within a region (e.g., producing in Mexico using U.S. inputs) (Humphrey, 2000). Also, political pressure on automakers to "build where they sell" affected their locational decisions (Sturgeon \& Van Biesebroeck, 2009).

The regionalization of final assembly in autos prompted the rise of global mega-suppliers, who rivaled the carmakers in profitability and technological capabilities (Foy, 2014). From the 1980s the outsourcing of parts supply continued to expand, leading automakers to spin off their parts production units, ${ }^{10}$ while regional production systems drove the consolidation of parts suppliers, promoting a two-tiered production structure within the automotive GVC. Lead firms needed established suppliers co-located in multiple regions, and suppliers with extensive international presence rose to assume an expanding role in parts production as well as R\&D (Sadler, 1999; Humphrey, 2003). This mix of regional production and global sourcing in automotive GVCs was partly attributed to the fact that political sensitivity to high imports was greater in finished vehicles than in auto parts, and automakers thus adjusted their production and sourcing strategies to trade rules and restrictions as well as political pressures (Sturgeon et al., 2008).

During the global financial crisis of the late 1990s, demand for autos plummeted. National governments created rescue packages for ailing automakers and parts suppliers. Due to their postcrisis effort to cut costs and rationalize supply chains, lead firms increasingly preferred working with a small set of first-tier suppliers with greater financial, technological, and managerial capabilities. This strengthened the supplier consolidation trend already underway in pre-crisis GVCs (Sturgeon \& Van Biesebroeck, 2009). Consolidation was also facilitated by new regulations, e.g., stricter safety and environmental standards (Barnes, 2017). At the same time, bilateral and regional trade agreements reinforced the regional configuration of the automotive GVC. Access to the U.S. and EU markets shaped the geography of the automotive GVCs by increasing the inflow of FDI into countries like Mexico as well as Slovakia and the Czech Republic, although the impact of FDI on technology spillovers and upgrading for local producers was not always positive (Pavlínek, 2015).

Finally, the development of new products, notably electric cars and autonomous vehicles, highlights the role of advanced technologies in restructuring automotive GVCs. They have facilitated the entry of new lead firms such as Tesla (the U.S.) and BYD (China) that compete with incumbent automakers. Along with technology giants like Google, novel breeds of specialized parts suppliers have emerged in the auto industry ecosystem as critical GVC actors in areas such as electric batteries and infotainment systems, creating a coevolution among suppliers and carmakers (PWC, 2019). Various trade restrictions and conflicts over advanced technology, as shown in the U.S.-China trade war, contribute to this disruptive realignment in the automotive GVC (Head \& Mayer, 2019).

\section{Electronics GVCs}

Historically, electronics has not been immune to trade restrictions. In the 1970s, as imports of consumer electronics from East Asia, notably Japan, Taiwan, and South Korea, surged in the U.S., trade restrictions such as orderly marketing arrangements (OMAs) were put in place by the U.S. government to limit their exports. In color televisions, for example, OMAs targeted Japan first and then expanded to Taiwan and Korea. A 3-year OMA with Japan in 1977 pushed down imports from Japan, but imports soared from Korea and Taiwan as U.S. buyers switched their offshore sourcing partners to non-Japanese firms. Restrictions over imports from Korea and Taiwan only led U.S. firms to switch again to importing unassembled TV sets (Irwin, 2019: 561-62). Overall, OMAs failed to curb consumer electronics imports from East Asia, and instead propelled the geographic dispersion of electronics manufacturing in the region.

Another notable trade dispute occurred between Japan and the U.S. over semiconductors. As Japan quickly expanded its world market share of computer chips in the early 1980s, threatened U.S. firms levelled charges of dumping and price manipulation against Japan. In 1986, the Japan-U.S. Semiconductor Agreement was established whereby Japan promised to widen market access to foreign chipmakers (Tyson, 1992; Baldwin, 1994). Although this trade agreement largely failed to expand the share of American firms in the Japanese market, it did redefine the structure of the semiconductor GVC. Many American chipmakers, who shifted their focus to chip design and sales, became "fabless" producers, while outsourcing chip fabrication to specialized manufacturers called "foundries." This vertical disintegration was accompanied by a geographic shakeup among semiconductor producers. Taiwan became the 
leader of an emerging foundry market, and Korea ventured into the memory chip market to undercut Japan's dominance. In contrast, Japanese firms failed to adapt to the end-market shift to personal computers (PC) and their prominence in the electronics GVC plummeted (Brown \& Linden, 2011).

The mid-1990s to late 2000s was characterized by trade liberalization with lowered tariffs in the electronics and information technology (IT) sector. Under the WTO's multilateral Information Technology Agreement (ITA), created in 1997, many electronic products became duty-free between major trading nations, facilitating cross-border trade of both finished and intermediate products. ${ }^{11}$ This pushed the evolution of the outsourcing model into a modular relationship between branded buyers and specialized suppliers, which was supported by industry-wide standards associated with the rise of "Wintelism" (Windows software plus Intel's semiconductors) in the PC value chain (Borrus \& Zysman, 1997). In this modular shift, value chain functions outside manufacturing were relegated by lead firms to so-called contract manufacturers. In response, suppliers gradually upgraded from OEM to ODM and electronics manufacturing service (EMS) roles in the electronics GVC, which included product design and other supporting functions (e.g., sourcing and logistics) to serve a wide range of buyers. ${ }^{12}$

The trade regulatory environment of the electronics/IT sector has continued to evolve over the last decade due to increasingly complicated crossborder digital trade (Daza Jaller, Gaillard \& Molinuevo, 2020). Meanwhile, China's approach to Internet governance, featured by cyber-nationalism, the dominance of the state (Wu \& Gereffi, 2019), and its emphasis on indigenous innovation, exemplified in the Made in China 2025 initiative, has raised tensions with foreign governments and multinational enterprises (MNEs) (Grimes \& Du, 2020). In recent years, the electronics GVC has become vulnerable to trade frictions and disputes over intellectual property rights (IPR)-related intangible assets such as software and algorithms. Supply chain security is a major concern for governments and firms as more infrastructure relies on complex IT and telecom systems that contain foreign valueadded products and technologies (The Economist, 2019).

The Apple-Foxconn model, based on a partnership between the world's most innovative and valuable IT brand and the world's largest Chinabased contract manufacturer, has become a template for electronics manufacturing since the late 2000s (Grimes \& Sun, 2016). At the same time, Chinese lead firms emerged to challenge Western MNEs in China and increasingly worldwide, notably Huawei (hardware), Alibaba (e-commerce), and Tencent (IT service and platforms). Their rise was attributed, on one hand, to the robust growth of the Chinese domestic market as well as other emerging-economy markets, which have facilitated a more polycentric international trade structure in the post-crisis world (Horner \& Nadvi, 2018). On the other hand, China's nationalistic and protectionist approach to the Internet facilitated the growth of its domestic lead firms (Wu and Gereffi, 2019). Against this background, the China-U.S. trade war not only threatens to undermine the Apple-Foxconn model, but also deals a significant blow to Chinese lead firms' growth prospects (Grimes \& Du, 2020).

At the same time, the trade war is prompting China-based firms in the electronics GVC to pursue switching and upgrading strategies in order to mitigate fallout from the trade war and potentially undermine the effectiveness of restrictive trade measures imposed by the U.S. and other nations. Many electronics brands and their suppliers are pondering production shifts from mainland China. Foxconn, the world's largest EMS provider and the primary producer of Apple's iPhone, has increased its investment and production in Vietnam, India and Brazil as well as switching some production back to Taiwan (Li \& Cheng, 2019). Chinese firms also began to use locations like Taiwan and Vietnam for the final assembly of imported semiassembled kits for U.S.-bound products, while setting up factories in offshore locations as a longerterm response (Guilford \& Kopf, 2019). They employ market and supplier switching strategies as well. Huawei, for instance, has diverted resources to the Chinese domestic market to offset its overseas slowdown, while ramping up sourcing from non-U.S. firms. Simultaneously, it has reinforced its upgrading effort by developing its own operating system called HarmonyOS and internalizing chip development to reduce its reliance on U.S. technology (Fitch \& Strumpf, 2019).

As a result of these trends, the complex and fragmented nature of the electronics GVCs can undermine the measures imposed by the U.S. government to curb technology exports to China. For instance, U.S. follow-up measures in 2020 to restrict both American and foreign firms from exporting semiconductors made using U.S. 
software and equipment to Huawei have not been effective thus far. This is mainly because alternative routes for technology exports to circumvent U.S. restrictions remain available to Taiwanese, Japanese, and Korean firms, which play key roles in the upstream (semiconductor design and equipment manufacturing) and midstream (fabrication, assembly and testing) segments of the semiconductor value chains (Bown, 2020). ${ }^{13}$

\section{DISCUSSION}

We have examined the evolution of GVC configurations in three GVC-intensive sectors: apparel, automotive, and electronics. Table 1 summarizes our findings with a focus on the role of trade policies and regulations in shaping the geographic and organizational configurations of GVCs, and the way the relation is mediated by the strategies of lead firms and suppliers. Overall, the findings support our general contention that there are recurrent "unintended consequences" of trade policies, both restrictions and trade agreements, and that firm strategies have supported an adaptive reconfiguration of GVCs, especially in East Asia. We outline the mechanisms for this claim below.

First, trade restrictions frequently resulted in contradictory outcomes. A series of trade restrictions, such as the MFA, VERs, and OMAs in the 1970s and 1980s, were actually not that effective in curbing imports from targeted countries; instead, they accelerated exporting firms' switching and upgrading moves, leading to the geographic reconfiguration of GVCs. Circumventive strategies like FDI-based transplants in autos enabled firms to jump over trade barriers, such as VERs, facilitating their internationalization and organizational restructuring. Meanwhile, trade liberalization worldwide in the 1990s and beyond did not necessarily result in a level playing field in trade. It created regionally concentrated structures in the automotive and electronics GVCs, with a growing number of regional trade agreements by the end of the 2000s. In the post-MFA apparel GVC, export activities were concentrated to China and other regional production hubs in Asia and Central America. These regional production systems were organizationally supported by consolidated transnational contract manufacturers or first-tier suppliers (Frederick \& Gereffi, 2011). Both American and foreign firms have responded to recent trade restrictions by the U.S. against China with various strategies of switching and upgrading, thereby undercutting the effectiveness of these trade measures.

Second, our analysis illuminates significant sectoral variation in the role of trade policies and firm strategies in reconfiguring GVCs. Different kinds of trade policies - e.g., import restriction versus export facilitation (Van Assche \& Gangnes, 2019) - were used in different periods, and firm strategies by both lead firms and suppliers generated distinctive GVC configurations in each sector. Trade restrictions like tariffs and quotas played an important role in the geographic expansion of apparel GVCs as firms kept moving production to locations with less regulation. VERs and quotas contributed to the internationalization of Japanese, German and Korean firms in automotive GVCs, but strong localization pressures constrained a full-blown global expansion as in apparel. Clustering in several regional hubs has become a major feature of automotive GVCs, whereas electronics GVCs have been highly concentrated in China and East Asia, where regional production ecosystems remain resilient despite the trade war.

Meanwhile, common temporal dynamics were observed across the sectoral cases. Bilateral restrictions by the U.S. and some European countries against East Asian exporters played a key role in all the GVCs during the first period (mid-1970s to mid1990s). The measures, however, failed to curtail the region's overall exports, and firms' strategic relocation led to the geographic diffusion and upgrading of export activities. During the second period, from the mid-1990s to the mid-2000s, the increase of preferential trade agreements, especially in North America and Europe, facilitated some level of regional agglomeration in all the sectors. The post-crisis shift to the third, and latest, stage (late 2000 s to the present) featured the growing geographic concentration of GVCs and the rise of consolidated transnational suppliers. Simultaneously, emerging markets such as China, India and Brazil have expanded fast, as have MNEs from those economies (Ramamurti \& Singh, 2009). Finally, trade issues have become more entangled with political and diplomatic conflicts amid the recent surge of anti-globalization, populist and nationalist sentiments (Dür, Eckhardt \& Poletti, 2020), while technological changes from automation to platform economies have brought techno-regulatory forces to the forefront in post-crisis GVCs (Sturgeon, 2019).

Third, while firm strategies - switching and upgrading - played a fundamental role that 
Table 1 Trade policies, firm strategies, and evolving GVC configurations.

\begin{tabular}{|c|c|c|c|}
\hline APPAREL & $\begin{array}{l}\text { Period I } \\
\text { Mid-1970s to mid-1990s }\end{array}$ & $\begin{array}{l}\text { Period II } \\
\text { Mid-1990s to mid-to-late 2000s }\end{array}$ & $\begin{array}{l}\text { Period III } \\
\text { Mid-to-late 2000s to the present }\end{array}$ \\
\hline $\begin{array}{l}\text { Trade policies } \\
\text { (restrictions; agreements) }\end{array}$ & $\begin{array}{l}\text { MFA-driven quota } \\
\text { scheme (1974-94) }\end{array}$ & $\begin{array}{l}\text { MFA phase-out (1995-2005); } \\
\text { preferential trade agreements } \\
\text { (NAFTA, 1994; AGOA, 2000; } \\
\text { CAFTA-DR, 2005) }\end{array}$ & $\begin{array}{l}\text { Post-MFA (2005-); bi- and multi- } \\
\text { lateral FTAs; US-China trade } \\
\text { war }\end{array}$ \\
\hline \multicolumn{4}{|l|}{ Firm strategies } \\
\hline Lead firms & $\begin{array}{l}\text { Managing a wide range of } \\
\text { independent suppliers }\end{array}$ & Investment in regional VCs & $\begin{array}{l}\text { Supply chain rationalization and } \\
\text { supplier consolidation in global } \\
\text { supply base }\end{array}$ \\
\hline Suppliers & $\begin{array}{l}\text { Low-cost-based integration } \\
\text { to GVCs; quota shopping } \\
\text { and internationalization }\end{array}$ & $\begin{array}{l}\text { Regional expansion with trade and } \\
\text { FDI; region-based, full-package } \\
\text { production }\end{array}$ & $\begin{array}{l}\text { Capability-building in } R \& D, \\
\text { design; managing multiple } \\
\text { offshore locations }\end{array}$ \\
\hline \multicolumn{4}{|l|}{ GVC configurations } \\
\hline Geography & Geographical dispersion & $\begin{array}{l}\text { Regional scope (North America, } \\
\text { Europe, Asia) }\end{array}$ & $\begin{array}{l}\text { Geographic concentration (e.g., } \\
\text { China, Bangladesh, Vietnam, } \\
\text { etc.); moving out from China }\end{array}$ \\
\hline Organization & $\begin{array}{l}\text { Triangular manufacturing } \\
\text { in Asia }\end{array}$ & $\begin{array}{l}\text { Regional textile sourcing; assembly- } \\
\text { based export processing }\end{array}$ & $\begin{array}{l}\text { The rise of transnational first-tier } \\
\text { suppliers (Global South) }\end{array}$ \\
\hline AUTOMOTIVE & $\begin{array}{l}\text { Period I } \\
\text { Late 1970s to mid-1990s }\end{array}$ & $\begin{array}{l}\text { Period II } \\
\text { Mid-1990s to mid-to-late 2000s }\end{array}$ & $\begin{array}{l}\text { Period III } \\
\text { Late } 2000 \text { s to the present }\end{array}$ \\
\hline $\begin{array}{l}\text { Trade policies } \\
\text { (restrictions; agreements) }\end{array}$ & $\begin{array}{l}\text { VER system for Japanese } \\
\text { carmakers }\end{array}$ & $\begin{array}{l}\text { Trade and investment } \\
\text { liberalization; regional } \\
\text { preferential trade agreements } \\
\text { (NAFTA; EU regionalization, } \\
\text { 1993) }\end{array}$ & $\begin{array}{l}\text { Bi- and multi-lateral FTAs; } \\
\text { tightened safety and } \\
\text { environmental standards; US- } \\
\text { China trade war }\end{array}$ \\
\hline \multicolumn{4}{|l|}{ Firm strategies } \\
\hline Lead firms & $\begin{array}{l}\text { Product upgrading to luxury } \\
\text { brands; transplant investment } \\
\text { in the US and Europe }\end{array}$ & $\begin{array}{l}\text { Investment in regional supply } \\
\text { base; growing outsourcing }\end{array}$ & $\begin{array}{l}\text { Supply chain rationalization; } \\
\text { new lead firms in next- } \\
\text { generation vehicles }\end{array}$ \\
\hline Suppliers & $\begin{array}{l}\text { Colocation in transplants; } \\
\text { taking advantage of cost- } \\
\text { cutting investment of foreign } \\
\text { carmakers }\end{array}$ & $\begin{array}{l}\text { Region-based supplier } \\
\text { colocation; supplier } \\
\text { consolidation }\end{array}$ & $\begin{array}{l}\text { Entry of new types of suppliers } \\
\text { (e.g., batteries, infotainment } \\
\text { system) }\end{array}$ \\
\hline \multicolumn{4}{|l|}{ GVC configurations } \\
\hline Geography & $\begin{array}{l}\text { Dispersion of final assembly; } \\
\text { design and technology still a } \\
\text { home (lead-firm MNEs) }\end{array}$ & $\begin{array}{l}\text { Regionalized value chains; co- } \\
\text { evolution of lead firms and } \\
\text { part suppliers }\end{array}$ & $\begin{array}{l}\text { More concentration to regional } \\
\text { production hubs }\end{array}$ \\
\hline Organization & $\begin{array}{l}\text { Design/technology } \\
\text { (headquarters) vs. final } \\
\text { assembly (offshore affiliates) }\end{array}$ & $\begin{array}{l}\text { Vertical disintegration of parts } \\
\text { production; the rise of global } \\
\text { mega-suppliers }\end{array}$ & $\begin{array}{l}\text { Co-evolution of lead firms and } \\
\text { part suppliers based on } \\
\text { technology \& partnerships }\end{array}$ \\
\hline ELECTRONICS & $\begin{array}{l}\text { Period I } \\
\text { Late 1970s to mid-1990s }\end{array}$ & $\begin{array}{l}\text { Period II } \\
\text { Mid-1990s to mid-to-late 2000s }\end{array}$ & $\begin{array}{l}\text { Period III } \\
\text { Mid-to-late 2000s to the present }\end{array}$ \\
\hline $\begin{array}{l}\text { Trade policies } \\
\text { (restrictions; agreements) }\end{array}$ & $\begin{array}{l}\text { VERs and OMAs for TVs (late } \\
\text { 1970s); trade disputes over } \\
\text { market opening (e.g., US- } \\
\text { Japan Semiconductor } \\
\text { Agreement, 1986) }\end{array}$ & $\begin{array}{l}\text { Trade liberalization with lower } \\
\text { tariffs (Information } \\
\text { Technology Agreement, 1997) }\end{array}$ & $\begin{array}{l}\text { Digital trade regulation } \\
\text { (internet governance models } \\
\text { - e.g., Great China Firewall; } \\
\text { e-commerce taxation; data } \\
\text { privacy) }\end{array}$ \\
\hline
\end{tabular}


Table 1 (Continued)

\begin{tabular}{|c|c|c|c|}
\hline ELECTRONICS & $\begin{array}{l}\text { Period I } \\
\text { Late 1970s to mid-1990s }\end{array}$ & $\begin{array}{l}\text { Period II } \\
\text { Mid-1990s to mid-to-late 2000s }\end{array}$ & $\begin{array}{l}\text { Period III } \\
\text { Mid-to-late 2000s to the present }\end{array}$ \\
\hline \multicolumn{4}{|l|}{ Firm strategies } \\
\hline Lead firms & $\begin{array}{l}\text { U.S. consumer electronics firms: } \\
\text { OEM production with East } \\
\text { Asian NIEs; U.S. } \\
\text { semiconductor firms: moving } \\
\text { to IPR-based business } \\
\text { ("fabless") while outsourcing } \\
\text { manufacturing to foundry }\end{array}$ & $\begin{array}{l}\text { Rise of "Wintelism" in PCs; } \\
\text { moving to design and } \\
\text { branding; outsourcing } \\
\text { manufacturing to contract } \\
\text { manufacturers }\end{array}$ & $\begin{array}{l}\text { Apple-Foxconn model; rise of } \\
\text { Chinese lead firms (e.g., } \\
\text { Huawei); prominence of } \\
\text { platform economy lead firms } \\
\text { (e.g., Amazon, Alibaba, } \\
\text { Google, Facebook) }\end{array}$ \\
\hline Suppliers & $\begin{array}{l}\text { Entering OEM/ODM models in } \\
\text { consumer electronics/IT; } \\
\text { entering semiconductor } \\
\text { foundry (Taiwan) and DRAM } \\
\text { segment (Korea) }\end{array}$ & $\begin{array}{l}\text { Evolving into EMS/CM models; } \\
\text { entering China for large-scale } \\
\text { low-cost production }\end{array}$ & $\begin{array}{l}\text { Colocation with CM in China } \\
\text { and other key locations; rise of } \\
\text { digital economy domestic } \\
\text { firms in China, India, other } \\
\text { Global South. }\end{array}$ \\
\hline \multicolumn{4}{|c|}{ GVC configurations } \\
\hline Geography & $\begin{array}{l}\text { Dispersion beyond U.S., Europe } \\
\text { and Japan to Taiwan, Korea } \\
\text { and other Asia }\end{array}$ & $\begin{array}{l}\text { Manufacturing expansion to } \\
\text { cost-cutting locations, } \\
\text { especially to China and Asia }\end{array}$ & $\begin{array}{l}\text { Further concentration to China; } \\
\text { growing FDI to other Asian } \\
\text { locations }\end{array}$ \\
\hline Organization & $\begin{array}{l}\text { Increased outsourcing in US } \\
\text { chains for consumer } \\
\text { electronics/ IT products; } \\
\text { vertical disintegration in } \\
\text { semiconductor (fabless and } \\
\text { foundry) }\end{array}$ & $\begin{array}{l}\text { Increased outsourcing; the rise } \\
\text { of global contract } \\
\text { manufacturers (e.g., Foxconn, } \\
\text { Flex, Celestica) }\end{array}$ & $\begin{array}{l}\text { CM model firmly put in place; } \\
\text { growing consolidation of } \\
\text { platform economy lead firms } \\
\text { through M\&As }\end{array}$ \\
\hline
\end{tabular}

MFA Multi-fiber arrangement, NAFTA North American Free Trade Agreement, AGOA African Growth and Opportunity Act, CAFTA-DR Dominican Republic-Central America Free Trade Agreement, FTA free trade agreement, $R \& D$ research and development, VER voluntary export restraint, $O M A$ orderly marketing arrangement, OEM original equipment manufacturing, NIE newly industrializing economies, IPR intellectual property rights, ODM original design manufacturing, DRAM dynamic random access memory, EMS electronics manufacturing service, CM contract manufacturing, VC value chain, $P C$ personal computer, $M \& A$ merger and acquisition.

mediated trade restrictions and GVC configurations, our study also illuminates a host of other factors that can influence firms' strategic choices and eventually shape GVC configurations, as illustrated in Figure $2 .{ }^{14}$ First of all, various sectoral characteristics affect firm strategies as well as the ensuing GVC configurations, including product characteristics, factor differences (e.g., labor-intensive vs. capital- or technology-intensive), and the levels of market concentration and political influence. Our study also highlights the overlap between trade policy, regulatory standards, FDI policies, and foreign exchange policies, which plays a significant role in fomenting the unintended consequences of trade restrictions. The elimination of the MFA in apparel and China's entry into the WTO both facilitated the upgrading of China's export prowess and increased industry concentration in ways that may have been unanticipated, and altered the international competitiveness of many countries in the GVC. Similarly, VERs and quotas in autos made Japan, Germany and Korea far tougher competitors for U.S. firms because they encouraged the growth of FDI and foreign auto transplants in the U.S. market. The unintended consequences generated by these overlapping and at time contradictory policies were not limited to the U.S. domestic economy only, but also are reflected in the multilateral institutions (like the WTO) and regional trade agreements that supported these GVCs (Eckhardt \& Poletti, 2018).

From a GVC perspective, we seek to understand how GVC governance structures might affect a firm's choices in the face of trade restrictions. Different governance structures, determined by transaction costs, codifiability and supplier capabilities (Gereffi et al., 2005), shape strategic options, costs and risks for the firms involved (Azmeh, 2019). For example, it would be easier to switch to alternative suppliers in market-based transactions than in relational ones. Firms with multiple sourcing locations across countries can switch 


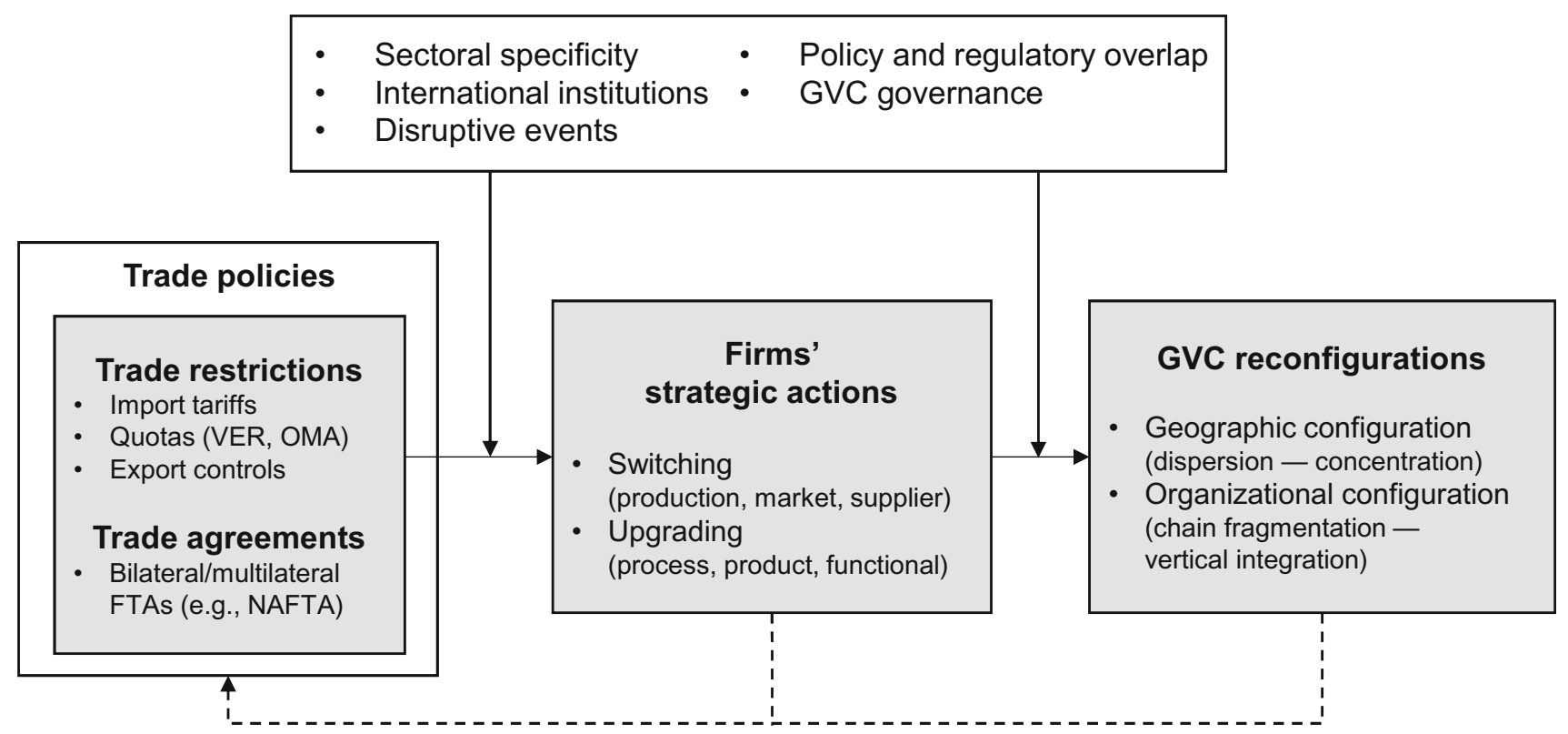

Source: Authors.

Figure 2 Trade policies, firm strategies and GVC restructuring: Analytical framework.

production easily (Head \& Mayer, 2019). By contrast, if a firm's supply chains are deeply embedded in a particular country, it would be much harder to find an alternative location with comparable scale and scope, and the switch would be costly (Ponte \& Sturgeon, 2014). The power of lead firms in affecting locational choices of their suppliers and enforcing supplier co-location amplifies the impact of lead firms' locational decisions (Dallas, Ponte \& Sturgeon, 2019).

Finally, disruptive events played a role in opening up new paths in GVC configurations. The bursting of the dot-com bubble in the early 2000s pushed many electronics/IT lead firms to sell or outsource their loss-making operations to contract manufacturers, redrawing the division between the two (Lee \& Gereffi, 2013). The global financial crisis significantly affected GVCs across sectors, prompting supply chain rationalization, geographic and organizational consolidation, and shifting the end market to the Global South (Cattaneo, Gereffi \& Staritz, 2010; Gereffi, 2014). Most recently, the global pandemic of COVID-19 and the ensuring disruptions have been unsettling GVCs more than ever (Gereffi, 2020; Van Assche \& Lundan, 2020).

In sum, all these factors can impact GVC configurations to varying degrees through firm strategies and they increase the likelihood of unintended consequences associated with trade policies in a world of GVCs. This finding casts new light on fruitful exchanges between the IB and GVC literatures (Gereffi, 2019a; McWilliam, Kim, Mudambi \& Nielsen, 2020). The former illuminates firm actors' strategic decision-making (Chi et al., 2019; Sako \& Zylberberg, 2019) to navigate uncertainty over GVC disruptions, while the latter highlights that firms are linked through distinctive forms of GVC governance, with varying degrees of power and resources to execute the strategies. Our analytical framework proposed in this article provides an interdisciplinary pathway to further interrogate the relationship among trade policies, firm strategies and GVC reconfigurations.

In addition, our framework sheds light on the future of GVCs amid the trade war and other GVC disruptions. As illustrated most recently by the electronics sector, the increasingly complicated nature of contemporary GVCs raises the possibility that any restrictive trade measures, including U.S. ones, will confront unintended and often undesirable consequences. As exemplified by Apple, Foxconn and Huawei, there is significant opportunity for firms to maneuver to circumvent trade restrictions through switching and upgrading. Yet, the actual outcome remains contingent upon a variety of related domestic and international policy 
measures, from trade and investment to innovation and upgrading, that can affect firms' strategic calculations, and may vary by sector and over time. While a disruptive event like the COVID-19 pandemic makes it extremely difficult to foresee the future, our historical case studies reveal that contrary to popular perception, trade restrictions did not necessarily bring about the shrinkage or demise of GVCs. Rather they are likely to trigger a new phase of reconfiguration where firms' strategic actions play a key part in shaping what comes next in GVCs.

\section{CONCLUSION: IMPLICATIONS FOR GVC-ORIENTED POLICY}

When it comes to GVC-oriented policy (Gereffi \& Sturgeon, 2013), our findings point to a dynamic role in upgrading and GVC reconfigurations. First, we need to reconsider the facilitative role of government policy in relation to GVCs. Policy measures with a "supply chain mindset" (Van Assche, 2017) were widely encouraged for local firms' integration to and upgrading in GVCs. Our results show, however, that governments can facilitate or hinder upgrading through trade policies, which may lead to unintended and contradictory outcomes at home and abroad. Lead firms and supplier strategies seek to circumvent policy barriers, and the structure of GVCs amplifies the impact of policy overlaps and the upgrading and switching moves of firms. Furthermore, as in the case of the U.S.-China trade war, government interventions may aim to sever GVC linkages and decouple the local industry from a targeted trade partner for economic or national security motives. ${ }^{15}$ Future research thus needs to revisit the variegated roles of the state in GVCs (Horner \& Alford, 2019), paying particular attention to planned or unexpected disruptions.

Second, given that trade restrictions often generate unintended consequences in a world of GVCs, policymakers should pay more attention to sectoral and temporal variations in how trade restrictions play out. GVCs consist of complex linkages across multiple geographies and organizations, and the impacts of the measures may vary across countries and firms depending on their location within the chains. East Asian economies have been particularly successful in the apparel, automotive and electronics GVCs in utilizing firm switching and upgrading strategies to circumvent trade restrictions and promote adaptive reconfigurations that foster resilient GVCs. A key question for future research is how firms in other regions of the world can learn from these experiences and develop their own distinctive responses to trade restrictions and other disruptions to GVCs, such as the digital transformation affecting all economies or global pandemics like COVID-19 (Pananond et al., 2020; Gereffi, 2020).

In particular, attention needs to be paid to how government policies in lead exporter and importer economies alike evolve in response to new GVC configurations mainly shaped by firms' strategic actions (see dotted lines in Figure 2). For example, China has tried to reduce its dependence on outward-oriented industrialization geared to the West in the face of rising external barriers to its exports, accelerating initiatives like Made in China 2025 to promote high-tech manufacturing and local innovation and "dual circulation" to redirect attention to its large domestic market (Gereffi, 2018b; Sheng, 2021). In the U.S., Europe and Asia, government policy has begun to push reshoring and automation themes aggressively in response to the willingness of firms to relocate their value chains amidst GVC disruptions caused by trade wars and the global pandemic of COVID-19 (Lighthizer, 2020; Kodachi, 2020). These examples highlight the dynamic interaction and co-evolution between GVC-oriented trade policies, firm strategies, and GVC configurations over time.

Finally, our article underscores the importance of focusing on state-business relations in GVCs. Compared to inter-firm governance, it is only recently that the developmental and institutional aspects of GVCs drew scholarly attention (Neilson \& Pritchard, 2009; Ge, Dollar \& Yu, 2020). GVCs should be conceived as a contested organizational terrain, where the institutionalization process of policy and governance measures are subject to political and economic confrontations among GVC actors, including lead firms, suppliers, nation-states, international institutions, and civil society organizations (Bair \& Palpacuer, 2015; Gereffi \& Lee, 2016; Werner \& Bair, 2019). Making and executing trade policy is no exception, and it warrants further study how trade policies and firm strategies interact to promote upgrading or downgrading in GVCs.

Future research could extend our three-sector case analysis with more systematic and fine-grained data on trade restrictions to better estimate their impact on GVCs and make our findings more generalizable. Furthermore, an in-depth study focusing on the decision-making process by lead 
firms and suppliers in response to GVC disruptions including trade restrictions would help us understand how firms and managers handle uncertainty in a geographically dispersed and organizationally fragmented production system.

\section{ACKNOWLEDGEMENTS}

Lim and Lee acknowledge the financial support provided by Samsung Economic Research Institute for their part of the research.

\section{NOTES}

${ }^{1}$ The Trump administration decided to withdraw from the Trans-Pacific Partnership (TPP) with 12 Pacific Rim countries, including the United States, that together comprised $40 \%$ of the global economy, and to renegotiate the North American Free Trade Agreement (NAFTA) with its two neighboring economies, Canada and Mexico. It also conducted a series of trade investigations to impose tariffs and quotas on a range of products from steel to solar panels. See Bown \& Kolb (2020) for the timeline of the Trump administration's trade-related moves.

${ }^{2}$ While the product is primarily manufactured in China, its key components and sub-assemblies are imported or domestically supplied by foreignowned firms, and thus most of the value-added is attributed to Korean, Japanese, German, and American tech giants, with very little left for assembly in China (Dedrick, Kraemer \& Linden, 2011).

${ }^{3}$ For other literature highlighting MNE decisionmaking, see real options theory and its application to international business (Chi, Li, Trigeorgis \& Tsekrekos, 2019) and research on the global factory (Buckley \& Strange, 2015).

${ }^{4}$ In May 2019, the U.S. government restricted American companies from doing business with Huawei without an official government permit, citing that Huawei posed a threat to U.S. national security. This decision has jeopardized the company's relationships with key business partners from Google as the provider of its Android mobile operating system to Intel and Qualcomm, its key chipset suppliers.

${ }^{5}$ These factors are addressed in the Discussion section below, in conjunction with Figure 2 .

${ }^{6}$ The Plaza Accord, signed in 1985, led to a sharp appreciation of East Asian local currencies vis-à-vis the U.S. dollar. Between 1985 and 1987, the Japanese yen was revalued by nearly $40 \%$, the New Taiwan dollar by $28 \%$, and the Korean won appreciated by 17\% from 1986 to 1988 (Gereffi, 1999: 51).

${ }^{7}$ This is contrary to the predictions of the "product life cycle" model that advanced economies exit an industry when the product becomes "mature" (Vernon, 1966; 1971: Ch. 3).

${ }^{8} \mathrm{~A}$ VER refers to a type of quota exercised by the government of an exporting country to voluntarily limit the quantity of a specific good that can be exported by the country to a given trading partner (Lutz, 2007).

${ }^{9}$ The policy measures played a role to pull foreign automakers to the locations where automotive production had previously been inactive, notably the U.S. South (Sturgeon \& Van Biesebroeck, 2009).

${ }^{10}$ For example, Denso was spun off from Toyota, Delphi from General Motors, and Visteon from Ford.

${ }^{11}$ The ITA was introduced by 29 WTO members, and currently it covers 81 members that account for $97 \%$ of world trade in IT products, according to the WTO (https://www.wto.org/english/tratop_e/ inftec_e/itaintro_e.htm).

${ }^{12}$ Leading contract manufacturers like Foxconn and Flex consolidated their position through mergers and acquisitions and the internalization of production networks. By the mid-2000s, they led the geographic expansion of electronics manufacturing in China and East Asia as well as a handful of emerging production hubs like Mexico, Brazil and Hungary (Sturgeon \& Kawakami, 2011).

${ }^{13}$ Despite the strong presence of U.S. firms in the fabless and integrated device manufacturing (IDM) segments of the semiconductor GVC, the U.S. only represents $5 \%$ of China's semiconductor imports while Taiwan, Korea, Malaysia and Japan together account for more than $70 \%$ in 2020 . In semiconductor manufacturing equipment, the U.S. still trails Japan, the world's largest exporter with $28 \%$ of global exports (Bown, 2020).

${ }^{14}$ The feedback loops (dotted lines in Figure 2) are discussed in the Conclusion section.

${ }^{15}$ Peter Navarro, the Director of Trade and Manufacturing Policy under the Trump administration, made it clear to the media that repatriating global supply chains was one of the administration's trade priorities (Donnan, 2017). 


\section{REFERENCES}

Autor, D. H., Dorn, D., \& Hanson, G. H. 2016. The China shock: Learning from labor-market adjustment to large changes in trade. Annual Review of Economics, 8: 205-240.

Azmeh, S. 2019. International trade policy and global value chains. In S. Ponte, G. Gereffi, \& G. Raj-Reichert (Eds.), Handbook on Global Value Chains: 523-538. Cheltemham, UK: Edward Elgar.

Bair, J., \& Gereffi, G. 2014. Towards better work in Central America: Nicaragua and the CAFTA Context. In A. Rossi, A. Luinstra, \& J. Pickles (Eds.), Towards Better Work: Understanding Labour in Apparel Global Value Chains: 251-275. Houndmills, UK: Palgrave Macmillan.

Bair, J., \& Palpacuer, F. 2015. CSR beyond the corporation: Contested governance in global value chains. Global Networks, 15(s1): S1-S19.

Baldwin, R. E. 1994. The impact of the 1986 US-Japan semiconductor agreement. Japan and the World Economy, 6(2): 129-152.

Barnes, J. 2017. The automotive GVC: Policy implications for developing economies. In J. Keane \& R. Baimbill-Johnson (Eds.), Future Fragmentation Processes: Effectively Engaging with the Ascendancy of Global Value Chains: 133-144. London: Commonwealth Secretariat.

Bellora, C., \& Fontagné, L. 2019. Trade wars and global value chains: Shooting oneself in the foot, VoxEU.org. 22 April, https://voxeu.org/article/trade-wars-and-global-value-chains. Accessed 15 August 2020.

Benjamin, D. K. 1999. Voluntary export restraints on automobiles. PERC Reports, 17(3): 16-17.

Blanchard, E. 2019. Trade wars in the global value chain era, VoxEU.org. 20 June, https://voxeu.org/article/trade-warsglobal-value-chain-era. Accessed 15 August 2020.

Borrus, M., \& Zysman, J. 1997. Globalization with borders: The rise of Wintelism as the future of global competition. Industry and innovation, 4(2): 141-166.

Bown, C. P. 2020. How Trump's export curbs on semiconductors and equipment hurt the U.S. technology sector. Peterson Institute for International Economics (PIIE) Trade and Investment Policy Watch, 28 September. https://www.piie.com/ blogs/trade-and-investment-policy-watch/how-trumpsexport-curbs-semiconductors-and-equipment-hurt-us. Accessed 25 December 2020.

Bown, C. P., \& Kolb, M. 2020. Trump's trade war timeline: An up-to-date guide, PIIE Trade and Investment Policy Watch. 6 August, https://www.piie.com/blogs/trade-investmentpolicy-watch/trump-trade-war-china-date-guide. Accessed 25 December 2020.

Brown, C., \& Linden, G. 2011. Chips and Change: How Crisis Reshapes the Semiconductor Industry. Cambridge, MA: MIT Press.

Buckley, P. J., \& Strange, R. 2015. The Governance of the global factory: Location and control of world economic activitity. Academy of Management Perspectives, 29(2): 237-249.

Cattaneo, O., Gereffi, G., \& Staritz, C. 2010. Global value chains in a postcrisis World: Resilience, consolidation, and shifting end markets. In O. Cattaneo, G. Gereffi, \& C. Staritz (Eds.), Global Value Chains in a Postcrisis World: A Development Perspective: 3-20. Washington, DC: World Bank.

Chi, T., Li, J., Trigeorgis, L. G., \& Tsekrekos, A. E. 2019. Real options theory in international business. Journal of International Business Studies, 50(4): 525-553.

Chor, D. 2019. The end of global supply chains as we know them?, East Asia Forum. 14 October, https://www. eastasiaforum.org/2019/10/14/the-end-of-global-supplychains-as-we-know-them/. Accessed 15 August 2020.

Curran, L., Nadvi, K., \& Campling, L. 2019. The influence of tariff regimes on global production networks (GPNs). Journal of Economic Geography, 19(4): 873-895.

Dallas, M. P., Ponte, S., \& Sturgeon, T. J. 2019. Power in global value chains. Review of International Political Economy, 26(4): 666-694.
Daza Jaller, L. Gaillard S \& Molinuevo, M. 2020. The Regulation of Digital Trade: Key Policies and International Trends. Washington, DC: World Bank, http://documents1. worldbank.org/curated/en/998881578289921641/pdf/TheRegulation-of-Digital-Trade-Key-Policies-and-InternationalTrends.pdf. Accessed 25 December 2020.

Dedrick, J., Kraemer, K. L., \& Linden, G. 2011. The distribution of value in the mobile phone supply chain. Telecommunications Policy, 35(6): 505-521.

Donnan, S. 2017. US trade chief seeks to reshore supply chain. Financial Times, 1 February, https://www.ft.com/content/ 8dc63502-e7c7-11e6-893c-082c54a7f539. Accessed 15 August 2020.

Dür, A., Eckhardt, J., \& Poletti, A. 2020. Global value chains, the anti-globalization backlash, and EU trade policy: A research agenda. Journal of European Public Policy, 27(6): 944-956.

Eckhardt, J., \& Poletti, A. 2018. Introduction: Bringing institutions back in the study of global value chains. Global Policy, 9(S2): 5-11.

Erken, H., Giesbergen, B., \& Nauta, L. 2019. US-China trade war: Which sectors are most vulnerable in the global value chain. Robobank RoboResearch, 14 August, https:// economics.rabobank.com/publications/2019/august/us-chinatrade-war-most-vulnerable-sectors/. Accessed 15 August 2020.

Fajgelbaum, P. D., Goldberg, P. K., Kennedy, P. I., \& Khandelwal, A. K. 2020. The return to protectionism. The Quarterly Journal of Economics, 135(1): 1-55.

Fitch, A., \& Strumpf, D. 2019. Huawei manages to make smartphones without American chips. The Wall Street Journal, 1 December, https://www.wsj.com/articles/huawei-managesto-make-smartphones-without-american-chips-11575196201. Accessed 15 August 2020.

Florida, R., \& Kenney, M. 1991. Transplanted organizations: The transfer of Japanese industrial organization to the U.S. American Sociological Review, 56(3): 381-398.

Foy, H. 2014. Age of mega supplier heralds danger for carmakers. Financial Times, 18 May, https://www.ft.com/ content/50c272c4-dce9-11e3-ba13-00144feabdc0. Accessed 15 August 2020.

Fratocchi, L., Di Mauro, C., Barbieri, P., Nassimbeni, G., \& Zanoni, A. 2014. When manufacturing moves back: Concepts and questions. Journal of Purchasing and Supply Management, 20(1): 54-59.

Frederick, S., \& Gereffi, G. 2011. Upgrading and restructuring in the global apparel value chain: Why China and Asia are outperforming Mexico and Central America. International lournal of Technological Learning, Innovation and Development, 4(1-3): 67-95

Fröbel, F., Heinrichs, J., \& Kreye, O. 1980. The New International Division of Labor: Structural Unemployment in Industrialised Countries and Industrialization in Developing Countries. Cambridge, UK: Cambridge University Press.

Ge, Y., Dollar, D., \& Yu, X. 2020. Institutions and participation in global value chains: Evidence from belt and road initiative. China Economic Review, 61: 101447, doi:https://doi.org/10. 1016/i.chieco.2020.101447.

Gereffi, G. 1994. The organization of buyer-driven global commodity chains: How US retailers shape overseas production networks. In G. Gereffi \& M. Korzeniewicz (Eds.), Commodity Chains and Global Capitalism: 95-122. Westport, CT: Praeger.

Gereffi, G. 1996. Commodity chains and regional divisions of labor in East Asia. Journal of Asian Business, 12(1): 75-112.

Gereffi, G. 1999. International trade and industrial upgrading in the apparel commodity chains. Journal of International Economics, 48(1): 37-70.

Gereffi, G. 2014. Global value chains in a post-Washington Consensus world. Review of International Political Economy, 21(1): 9-37. 
Gereffi, G. 2018a. Global Value Chains and Development: Redefining the Contours of 21 st Century Capitalism. Cambridge, UK: Cambridge University Press.

Gereffi, G. 2018b. Protectionism and global value chains. In G. Gereffi, Global Value Chins and Development: Redefining the Contours of $21^{\text {st }}$ Century Capitalism: 429-452. Cambridge, UK: Cambridge University Press.

Gereffi, G. 2019a. Global value chains and international development policy: Bringing firms, networks and policy-engaged scholarship back in. Journal of International Business Policy, 2(3): 195-210.

Gereffi, G. 2019b. Economic upgrading in global value chains. In S. Ponte, G. Gereffi, \& G. Raj-Reichert (Eds.), Handbook on Global Value Chains: 240-254. Cheltenham, UK: Edward Elgar Publishers.

Gereffi, G. 2020. What does the COVID-19 pandemic teach us about global value chains? The case of medical supplies. Journal of International Business Policy, 3(3): 287-301.

Gereffi, G., Humphrey, J., \& Sturgeon, T. 2005. The governance of global value chains. Review of International Political Economy, 12(1): 78-104.

Gereffi, G., \& Lee, J. 2016. Economic and social upgrading in global value chains and industrial clusters: Why governance matters. Journal of Business Ethics, 133(1): 25-38.

Gereffi, G., \& Sturgeon, T. J. 2013. Global value chain-oriented industrial policy: The role of emerging economies. In D. K. Elms \& P. Low (Eds.), Global Value Chains in a Changing World: 329-360. Geneva: World Trade Organization, Fung Global Institute and Temasek Foundation Centre for Trade \& Negotiations.

Grimes, S., \& Du, D. 2020. China's emerging role in the global semiconductor value chain. Telecommunications Policy, doi: https://doi.org/10.1016/j.telpol.2020.101959.

Grimes, S., \& Sun, Y. 2016. China's evolving role in Apple's global value chain. Area Development and Policy, 1(1): 94-112.

Grunwald, J., \& Flamm, K. 1985. The Global Factory: Foreign Assembly in International Trade. Washington DC: Brookings Institution Press.

Guilford, G., \& Kopf, D. 2019. The trade war is already pushing businesses out of China-and it could be permanent. Quartz, 14 June, https://qz.com/1641598/trumps-trade-war-withchina-is-reshaping-global-trade/. Accessed 15 August 2020.

Head, K., \& Mayer, T. 2019. Brands in motion: How frictions shape multinational production. American Economic Review, 109(9): 3073-3124.

Horner, R., \& Alford, M. 2019. The roles of the state in global value chains. In S. Ponte, G. Gereffi, \& G. Raj-Reichert (Eds.), Handbook on Global Value Chains: 557-571. Cheltenham: Edward Elgar.

Horner, R., \& Nadvi, K. 2018. Global value chains and the rise of the Global South: Unpacking twenty-first century polycentric trade. Global Networks, 18(2): 207-237.

Humphrey, J. 2000. Assembler-supplier relations in the auto industry: Globalisation and national development. Competition \& Change, 4(3): 245-271.

Humphrey, J. 2003. Globalization and supply chain networks: The auto industry in Brazil and India. Global Networks, 3(2): 121-141.

Humphrey, J., \& Schmitz, H. 2002. How does insertion in global value chains affect upgrading in industrial clusters? Regional Studies, 36(9): 1017-1027.

Irwin, D. A. 2019. Clashing over Commerce: A history of US Trade Policy. Chicago: The University of Chicago Press.

Kodachi, H. 2020. Japan to help bring home factories that left after 2011 disaster. Nikkei Asian Review, 25 March, https://asia. nikkei.com/Politics/Japan-to-help-bring-home-factories-thatleft-after-2011-disaster. Accessed 15 August 2020.

Lee, J., \& Gereffi, G. 2013. The co-evolution of concentration in mobile phone global value chains and its impact on social upgrading in developing countries. Capturing the Gains Working Paper 2013/25: University of Manchester, http:// www.capturingthegains.org/publications/workingpapers/wp 201325.htm. Accessed 15 August 2020.

Lee, J., Gereffi, G., \& Beauvais, J. 2012. Global value chains and agrifood standards: Challenges and possibilities for smallholders in developing countries. Proceedings of the National Academy of Sciences, 109(31): 12326-12331.

Li, L., \& Cheng, T.-F. 2019. Key Apple suppliers ready more nonChina production. Nikkei Asian Review, 13 November, https:// asia.nikkei.com/Economy/Trade-war/Key-Apple-suppliers-readymore-non-China-production. Accessed 15 August 2020.

Lighthizer, R. E. 2020. The era of offshoring U.S. jobs is over. New York Times, 11 May, https://www.nytimes.com/2020/05/ 11/opinion/coronavirus-jobs-offshoring.html. Accessed 15 August 2020.

Lutz, S. 2007. Import quotas and voluntary export restraints. In W. A. Kerr \& J. D. Gaisford (Eds.), Handbook on International Trade Policy: 248-257. Cheltemham, UK: Edward Elgar Publishing.

Matousek, M. 2018. Tesla said it expects tariffs on Chinese parts to cost around $\$ 50$ million during Q4. Business Insider, 24 October, https://www.businessinsider.com/tesla-tariffschinese-parts-cost-50-million-q4-2018-10. Accessed 15 August 2020.

McWilliam, S. E., Kim, J. K., Mudambi, R., \& Nielsen, B. B. 2020. Global value chain governance: Intersections with international business. Journal of World Business, 55(4): 101067, doi: https://doi.org/10.1016/j.jwb.2019.101067.

Morris, M., Staritz, C., \& Barnes, J. 2011. Value chain dynamics, local embeddedness, and upgrading in the chothing sectors of Lesotho and Swaziland. International Journal of Technological Learning, Innovation and Development, 4(1-3): 96-119.

Navas-Alemán, L. 2011. The impact of operating in multiple value chains for upgrading: The case of the Brazilian furniture and footwear industries. World Development, 39(8): 13861397.

Neilson, J., \& Pritchard, B. 2009. Value Chain Struggles: Institutions and Governance in the Plantation Districts of South India. Chichester, West Sussex: Wiley-Blackwell.

OECD. 2013. Interconnected Economies: Benefiting from Global Value Chains. Paris: OECD Publishing.

Pananond, P., Gereffi, G., \& Pedersen, T. 2020. An integrative typology of global strategy and global value chains: The management and organization of cross-border activities. Global Strategy Journal, 10(3): 421-443.

Pavlínek, P. 2015. The impact of the 2008-2009 crisis on the automotive industry: Global trends and firm-level effects in Central Europe. European Urban and Regional Studies, 22(1): $20-40$.

Ponte, S., \& Sturgeon, T. 2014. Explaining governance in global value chains: A modular theory-building effort. Review of International Political Economy, 21(1): 195-223.

PWC. 2019. Merge ahead: Electric vehicles and the impact on the automotive supply chain, November, https://www.pwc. com/us/en/industries/industrial-products/library/electric-vehiclessupply-chain.html. Accessed 15 August 2020.

Ramamurti, R., \& Singh, J. V. 2009. Emerging multinationals in emerging markets. Cambridge, UK: Cambridge University Press.

Rudd, K. 2020. Beware the guns of August - in Asia. How to keep U.S.-Chinese tensions from sparking a war. Foreign Affairs, 3 August, https://www.foreignaffairs.com/articles/united-states/ 2020-08-03/beware-guns-august-asia. Accessed 25 December 2020.

Sadler, D. 1999. Internationalization and specialization in the European automotive components sector: Implications for the hollowing-out thesis. Regional Studies, 33(2): 109-119.

Sako, M., \& Zylberberg, E. 2019. Firm-level strategy and global value chains. In S. Ponte, G. Gereffi, \& G. Raj-Reichert (Eds.), Handbook on Global Value Chains: 340-353. Cheltemham, UK: Edward Elgar. 
Sheng, A. 2021. Dual circulation is a strategic process, not a theory. East Asia Forum, January 20, https://www. eastasiaforum.org/2021/01/20/dual-circulation-is-a-strategicprocess-not-a-theory/. Accessed 31 January 2021.

Sturgeon, T. J. 2021. Upgrading strategies for the digital economy. Global Strategy Journal, 11(1), 34-57.

Sturgeon, T. J., \& Florida, R. 2004. Globalization, diverticalisation and employment in the motor vehicle industry. In M. Kenney (Ed.), Locating Global Advantage: Industry Dynamics in a Globalizing Economy. Stanford, Calif.: Stanford University Press.

Sturgeon, T. J., \& Kawakami, M. 2011. Global value chains in the electronics industry: Characteristics, crisis, and upgrading opportunities in firms from developing countries. International Journal of Technological Learning, Innovation and Development, 4(1-3): 120-147.

Sturgeon, T. J., \& Van Biesebroeck, J. 2009. Crisis and protection in the automotive industry. Policy Research Working Paper 5060. Washington DC: The World Bank, September, http://documents. worldbank.org/curated/en/357861468315545086/Crisis-andprotection-in-the-automotive-industry-a-global-value-chainperspective. Accessed 15 August 2020.

Sturgeon, T. J., Van Biesebroeck, J., \& Gereffi, G. 2008. Value chains, networks and clusters: Reframing the global automotive industry. Journal of Economic Geography, 8(3): 297-321.

Swanson, A., \& Rapperport, A. 2020. Trump signs China trade deal, putting economic conflict on pause. New York Times, 16 January, https://www.nytimes.com/2020/01/15/business/ economy/china-trade-deal.html. Accessed 15 August 2020.

The Economist. 2019. Special report on global supply chains. The Economist, July 13.

Tyson, L. D. A. 1992. Who's Bashing Whom? Trade Conflict in High-Technology Industries. Washington DC: Institute for International Economics.

UNCTAD. 2013. World Investment Report 2013-Global Value Chains: Investment and Trade for Development. Geneva: United Nations Conference on Trade and Development.

UNCTAD. 2019. Key Statistics and Trends in Trade Policy 2018: Trade Tensions, Implications for Developing Countries. Geneva: United Nations Conference on Trade and Development.

Van Assche, A. 2017. Global value chains and the rise of a supply chain mindset. In S. Tapp, A. Van Assche, \& R. Wolfe (Eds.), Redesigning Canadian Trade Policies for New Global Realities: 183-208. Montreal, Quebec: The Institute for Research on Public Policy.

Van Assche, A., \& Gangnes, B. 2019. Production switching and vulnerability to protectionism. In R. van Tulder, A. Verbeke, \& B. Jankowska (Eds.), International Business in a VUCA World: The Changing Role of States and Firms (Progress in International Business Research, Vol. 14): 69-87. Bingley, UK: Emerald Publishing Limited.

Van Assche, A., \& Lundan, S. 2020. From the editor: COVID-19 and international business policy. Journal of International Business Policy, 3(3): 273-279.

Vernon, R. 1966. International investment and international trade in the product cycle. The Quarterly Journal of Economics, 80(2): 190-207.

Vernon, R. 1971. Sovereignty at Bay: The Multinational Spread of U.S. Entreprises. New York: Basic Books.

Werner, M., \& Bair, J. 2019. Global value chains and uneven development: A disarticulations perspective. In S. Ponte, G. Gereffi, \& G. Raj-Reichert (Eds.), Handbook on Global Value Chains: 183-198. Cheltenham, UK: Edward Elgar Publishers.
World Bank. 2020. World Development Report: Trading for Development in the Age of Global Value Chains. Washington, DC: The World Bank.

Wu, X., \& Gereffi, G. 2019. Amazon and Alibaba: Internet governance, business models, and internationalization strategies. In R. van Tulder, A. Verbeke, \& L. Piscitello (Eds.), International Business in the Information and Digital Age (Progress in International Business Research, Vol. 13): 327356. Bingley, UK: Emerald Publishing Limited.

\section{ABOUT THE AUTHORS}

Gary Gereffi (B.A., Notre Dame; MPhil \& PhD, Yale University) is an Emeritus Professor at Duke University and the Founding Director of the Duke Global Value Chains Center. Gereffi has published numerous books and articles on globalization, industrial upgrading, and social and economic development in various parts of the world. His books include: Commodity Chains and Global Capitalism (Praeger Publishers, 1994); Global Value Chains in a Postcrisis World: A Development Perspective (The World Bank, 2010); Global Value Chains and Development: Redefining the Contours of 21st Century Capitalism (Cambridge University Press, 2018); and Handbook on Global Value Chains (Stefano Ponte, Gary Gereffi, and Gale RajReichert, co-editors), Cheltenham, UK: Edward Elgar Publishing, 2019.

Hyun-Chin Lim is Professor Emeritus of Sociology and Director of Civil Society Program, Seoul National University. He is also Elected Member, National Academy of Sciences, Republic of Korea. His main areas of research include global civil society, sociology of development, comparative capitalism, and democracy, focusing on Asia and Latin America.

Joonkoo Lee is Associate Professor of Organization Studies at the School of Business, Hanyang University in Seoul. His main areas of research include globalization and development, specifically global and regional value chains, value chain governance, and economic and social upgrading in apparel, electronics and cultural/creative industries, focusing on Asia.

Publisher's Note Springer Nature remains neutral with regard to jurisdictional claims in published maps and institutional affiliations.

Accepted by Carlo Pietrobelli, Guest Editor, 14 January 2021. This article has been with the authors for three revisions' 